\title{
EVALUATION OF THE PRESERVATION STATE OF HISTORICAL PENINSULA IN ISTANBUL BASED ON GEOSPATIAL DATA
}

\author{
Y. Can ${ }^{1}$, S. Tura ${ }^{1}$, E. Kudde ${ }^{1 *}$ \\ ${ }^{1}$ Istanbul Metropolitan Municipality, 34134 Fatih ISTANBUL, Turkey - (yelizzcann, salihtura, esrakudde13)@gmail.com
}

KEY WORDS: Cultural Heritage, Data Analysis, GIS, Thematic Map, Geospatial Data

\begin{abstract}
:
Inventory Project for the Cultural Assets of Istanbul (2015-2019) revealed that there are approximately 35000 historical and cultural assets in Istanbul due to its history with regards to being homeland and capital of many different civilizations. Historical Peninsula (Fatih district) which also contains four World Heritage Sites listed by UNESCO has $30 \%$ of the total registered historical assets inventory in Istanbul. Throughout the inventory project for the cultural assets of Istanbul, huge amount of data was collected by sitework with their spatial references. Cultural assets' database was related with the spatial data on GIS software and it will serve as a tool for various analyses in order to understand and evaluate the situation. Essentially 11 analyses were generated from inquirable geospatial data for Historical Peninsula of Istanbul. Geospatial data is constituted of approximately 140 distinct data-type including location, architectural description, conservation state, materials or cultural era that can be useful for different analyses and also crossexamine such as non-functional assets on public property or structural state of assets which require an urgent intervention. In addition, specific thematic maps and different routes for touristic and cultural purposes can be produced on GIS platforms, based on this study. In this paper, these mentioned studies of the Inventory Project of Istanbul will be described in detail and several case studies generated for the Historical Peninsula will be presented. It is aimed to define a data processing methodology created for cultural heritage by using GIS platforms in order to be evaluated in further projects.
\end{abstract}

\section{INTRODUCTION}

\subsection{General Background}

Located strategically between the Balkans, Anatolia, the Black Sea and the Mediterranean, Istanbul has been a capital city of the Eastern Roman Empire and the Ottoman Empire, and has been associated with many important events in the history of politics, history of religions and art history for more than 2000 years. Istanbul's outstanding universal value lies in its unique architectural assets reflecting the combination of Asia and Europe and its exclusive silhouette created by genius Byzantine and Ottoman architects.

Inventory Project for the Cultural Assets of Istanbul (20152019) revealed that there are approximately 35000 historical and cultural assets in Istanbul. Majority of these cultural assets (approximately 30\%) are located in Historical Peninsula (Fatih district) which also contains four World Heritage Sites listed by UNESCO.

In this paper methodology, data creation process, data types, data validation will be mentioned and explained thoroughly. Zeyrek World Heritage Site will be given as an example for outcome of the study and some analyses will be discussed.

\subsection{Scope}

Inventory Project for the Cultural Assets of Istanbul is a project carried out by Cultural Heritage Conservation Directorate of Istanbul Metropolitan Municipality. The project was estimated to be finished in 5 years and the scope is entire Istanbul including every district.

\subsection{Aim}

The need for accurate and accessible data about cultural assets plays the main role for this project. In 2010, with the declaration of European Capital of Culture a project was launched for cultural assets. This previous work was considered as a reference in order to carry out the process. But unfortunately the previous work has its flaws; it is not entirely accurate and accessible, and not entirely completed. There were also some inadequacies in the context of spatial data. To rule out all these deficiencies and create an accessible, accurate, inquirable, sustainable and geo-referenced database for cultural assets this project launched by Istanbul Metropolitan Municipality in 2015.

\subsection{Methodology}

Project team is multi-disciplinary and has experts from several different fields like architects, conservators, urban planners, art historians and archaeologists.

In methodology section geo-spatial data and its process will be presented. The process starts with literature research that consists of browsing archives for rulings of the Preservation Boards, old photographs, sketches, reports and old inventory records. Old maps like Pervititch, Goad Plans, and German Maps were georeferenced to their corresponding positions in order to provide a base for cultural assets and overlay analyses. The next step is the creation of the district maps based on literature research with block-parcel and base map references for in-situ work. Map creation data is finalized after the comparison process with year 2010 data.

In the first phase (Uskudar, Eyupsultan districts, 2015) field work was barely composed of taking structural and technical

\footnotetext{
* Corresponding authors
} 
notes together with current-state photos. However, there is no geo-spatial data production in the field.

In the next phases (starting from 2016) spatial data was introduced into field work via a newly developed software exclusively for this project. With the aid of mobile devices/tablets, feature data and spatial counterpart was built and linked easily during this process and records were imported into database in one step. This approach assures not only increasing time efficiency but also reducing cost. In spite of the rapid and effective data production in the field, it does bring also certain problems and disadvantages which caused by both users and software. Inaccuracies in spatial data production, integration problems between features and spatial data can be considered as unfavourable sides. A comparison and crosscheck between GIS and WebGIS (software developed IMOS) platform is required and advised to eliminate such errors. Accurate and valid spatial data needs to be generated and integrated with feature data acquired from field work by using block-parcel numbers, old maps, and old photos as a reference. Another practise is the identification of overlapped spatial data of different assets, which means in real world, assets have different locations but same $\mathrm{x}$ and $\mathrm{y}$ coordinates were designated in field work due to an error originated from user or software. Proceeding through this elaborative procedure assures outcome to be error-free and accurate.

\begin{tabular}{|l|l|}
\hline \multicolumn{2}{|l|}{ Properties of Database } \\
\hline Geographic Coordinate System & GCS_WGS_1984 \\
Angular Unit & Degree \\
Prime Meridien & $(0,0174532925199433)$ \\
Datum & Greenwich(0,0) \\
Spheroid & D_WGS_1984 \\
Column Spacing & WGS_1984 \\
\hline
\end{tabular}

Table 1. Properties of Istanbul Cultural Inventory Database

\section{GEO-SPATIAL DATA}

After the preparation phase, the database is ready for using to create distinctive outputs. 11 significant analyses were generated with the controlled and accurate data for specific areas which are world heritage sites and various protected areas and also each neighbourhood of all districts in Istanbul. All the records situated inside the site border evaluated for the registry state and ownership analyses. In addition to these evaluations, a case study will be discussed, several additional products will be mentioned and further projects will be exemplified.

\subsection{Spatial Analyses}

Registry State focused on rulings of the Preservation Boards that specify preservation degree types for monuments like $1^{\text {st }}$ degree and $2^{\text {nd }}$ degree. However, some monuments are not classified in terms of degree types but they will be taking part on the analysis as unknown degree. Besides, non-registered original assets are shown only in this analysis, as proposals.

In Ownership evaluation only registered assets were taken into account and it contains property holder types in the way that general titles such as public, foundation, private, association. In database, every details of owner were documented such as who is responsible for maintenance or certain property holder; it can be a person, an institution or partnership of different shareholders.

Type of Monument focused on the monument types of registered and it is also up to rulings of Preservation Boards. Whole database of Istanbul includes 152 types of monument as mosque, church, tomb, fountain, city wall, aqueduct, light railway etc. Variety of the monument type is valuable but in the analysis stage main headings like administrative, civil architecture, commercial, education, health, industrial, military, religious, service, social and cultural, transportation, water and urban element are identified. When checking the rulings of Preservation Boards, several cases emerged and classified as mixed, for instance apartment and store as a monument type.

Missed Cultural Assets mention monuments which could not reach present-day, and the analysis shows the details on monument types such as house, tower, pier etc. If there are some building on the parcel of the missed cultural assets, the characteristics of the new one is recorded too.

Construction Technique analysis was generated by excluding religious areas (graveyards and burial sites), shows the numerous different types of structure classified as masonry, timber frame, concrete frame, and steel frame. In addition to these titles, there are assorted combinations between masonry and frame types that called as mixed.

State of Conservation shows current situation of the assets which are registered in terms of physical conditions. In this analysis, assets currently under construction were eliminated. There are three groups on the analysis; good, medium and ruin. Yellow to red colour gradient was assigned to provide a better understanding of the map.

Analysis of Function is based on up-to-date usage that is determined on the field work of the assets. This evaluation comprises registered and currently existing assets. Database of entire work contains 127 types of function; meanwhile, similar to monument types analysis, specific classification defined as administrative, commercial, education, health, industrial, military, residential, religious, service, social and cultural, transportation, and urban element. On the field work several assets that have more than one function were encountered commonly and these kinds of combinations are identified as mixed use. Besides, some different cases occurred that cannot be classified under the mentioned headings; a part of assets are under construction, remarkable amount of assets are out of use and also some assets could not be identified on the field, due to high garden walls, closed doors or private property, therefore their function cannot be determined.

After the evaluation of assets' current function, Functional Originality was discussed. This analysis is a comparison between the monument type and its usage of the present-day. According to result of interpretation, assets which are maintaining the monument type identified as original; on the other hand, lots of assets that have a different function than its monument type, classified as non-original. In addition to this categorization, another description is created for the underconstruction areas and vacant parcels, named as non-functional.

Original assets which are specified from the functional originality evaluation, are analysed about their monument type but not using the main headings. Originally Used Assets 


\begin{tabular}{|c|c|c|c|c|c|c|c|c|c|}
\hline ID & $\begin{array}{l}\text { Registry } \\
\text { Status } \\
\end{array}$ & $\begin{array}{l}\text { Monument } \\
\text { Type }\end{array}$ & Function & $\begin{array}{l}\text { Existing / } \\
\text { Missed } \\
\end{array}$ & $\begin{array}{l}\text { Constructio } \\
\mathrm{n} \text { Technique }\end{array}$ & $\begin{array}{l}\text { State of } \\
\text { Conservation }\end{array}$ & $\begin{array}{l}\text { Functional } \\
\text { Originality }\end{array}$ & $\begin{array}{l}\text { Physical } \\
\text { Function }\end{array}$ & Ownership \\
\hline 5000 & 2. degree & $\begin{array}{l}\text { civil } \\
\text { architecture }\end{array}$ & commercial & existing & mixed & medium & $\begin{array}{l}\text { non- } \\
\text { original }\end{array}$ & partly renewed & private \\
\hline 5001 & 2. degree & $\begin{array}{l}\text { civil } \\
\text { architecture }\end{array}$ & $\begin{array}{l}\text { civil } \\
\text { architecture }\end{array}$ & existing & $\begin{array}{l}\text { timber } \\
\text { frame }\end{array}$ & good & original & original & foundation \\
\hline 5002 & proposal & water & out of use & existing & masonry & ruin & $\begin{array}{l}\text { non- } \\
\text { functional }\end{array}$ & partly renewed & public \\
\hline 5003 & 1. degree & $\begin{array}{l}\text { civil } \\
\text { architecture }\end{array}$ & & missed & & & & & private \\
\hline 5004 & 1. degree & religious & religious & existing & masonry & good & original & original & public \\
\hline 5005 & 1. degree & religious & & missed & & & & & association \\
\hline 5006 & non-defined & urban element & urban element & existing & masonry & good & original & original & public \\
\hline 5007 & 1. degree & $\begin{array}{l}\text { administrativ } \\
\mathrm{e}\end{array}$ & $\begin{array}{l}\text { administrativ } \\
\mathrm{e}\end{array}$ & existing & mixed & medium & original & mostly renewed & foundation \\
\hline 5008 & 2. degree & industrial & $\begin{array}{l}\text { under } \\
\text { construction }\end{array}$ & existing & steel frame & & $\begin{array}{l}\text { non- } \\
\text { functional }\end{array}$ & reconstruction & private \\
\hline 5009 & proposal & education & $\begin{array}{l}\text { social and } \\
\text { cultural }\end{array}$ & existing & $\begin{array}{l}\text { concrete } \\
\text { frame }\end{array}$ & good & $\begin{array}{l}\text { non- } \\
\text { original }\end{array}$ & mostly renewed & private \\
\hline 5010 & non-defined & health & & missed & & & & & public \\
\hline
\end{tabular}

Table 1. Distinct Data Types Used For Spatial Analyses

analysis shows which monuments could reach to present-day with their original function.

Another originality definition mentions about Physical Originality analysis with the comparison between original physical or architectural characteristics of monument and its current situation. As reported by the evaluation, some assets maintain its original physical condition completely and some assets are renewed partly or mostly. Also, there are some reconstructions and new buildings. All this kind of decisions done with observations on field work, old and new photographs, old maps and blueprint projects.

In physical originality evaluation, original assets are analysed in terms of their monument type, too. Originally Conserved Assets map shows monuments that was able to reach to present-day with their original physical and architectural aspects.

\subsection{Case Study: Zeyrek World Heritage Site}

This study's spatial analyses focused on one of the important World Heritage Site is known as 'Zeyrek'. Zeyrek site includes 238 listed buildings in the area that its covers 10.5 ha. Registry state analysis shows the richness of the 2 . degree assets which consist of fountain, wall, gate, store, house, mansion, and cistern. Besides, several assets do not have the preservation degree, which should be ruled by Preservation Boards; and also original 3 buildings determined as proposals according to their structural characteristics, architectural style and construction period. Evaluation about ownership shows that almost all of assets are in private property. In type of monument analysis, a great majority of assets are civil architecture and also there are 6 classifications such as administrative, education, religious, urban element, water and mixed. According to another important analysis, there are 68 missed cultural assets; 60 of them house and also an annex, a bath, a cistern, a fountain, a madrasah, a wall, a water reservoir are identified. Construction system evaluations formed with 156 assets which are particularly masonry and timber frame. There are not only reconstruction concrete frame buildings in the site, but also mixed construction styles such as timber frame-brick masonry, concrete frame-stone masonry, timber frame-concrete frame, timber frame-stone masonry. State of conservation analysis shows half of the assets are in medium situations. Current function of assets interpretation, it is seemed that half of the records is in residential use and other categorizations are administrative, commercial, education, religious, social and cultural, urban element and mixed use. Also there are several assets which are out of use. The comparison between monument type and current function reflects the majority of assets are preserve their originality. In this site, 91 assets are original in terms of function; apartment, cemetery, house, ministry, mosque, wall, store-house, and tomb. Another evaluation is discussed according to their original physical form. 29 assets, are preserved in physical structure, which can be varied as cemetery, cistern, house, mansion, mosque, wall, and water reservoir.

\subsection{Additional Products}

Geo-spatial analyses listed above are standard for the whole project scope; however, database has so much more to offer, it provides a basis for many different and various types of further studies since it includes a huge amount of inquirable data.

Thematic maps were developed around the Historical Peninsula (Fatih district) along with particular approaches. All registered educational facilities were selected from database and it is revealing monument types such as darülkurra and darülhadis (both Islamic schools), library, madrasah (medrese), university, and sibyan mektebi (it is a specific Ottoman school for younglings).

Another thematic map was generated to exhibit the construction period of baths between 15th to 19th centuries. In addition, a map of inns that focused on commerce centre of Fatih were created also in manner of construction periods. The inn map will serve as a template for specific tourist and commerce route of old nucleus of the city. It has general information about the location, short history and some other features about structural details.

Geo-spatial promoted database, has substantial inputs, which is sufficient to generate different inventory. Beside cultural assets, inscription inventory is prepared together with their transcriptions, meaning in Turkish (they are generally written in Ottoman or Arabic) and also various features. 


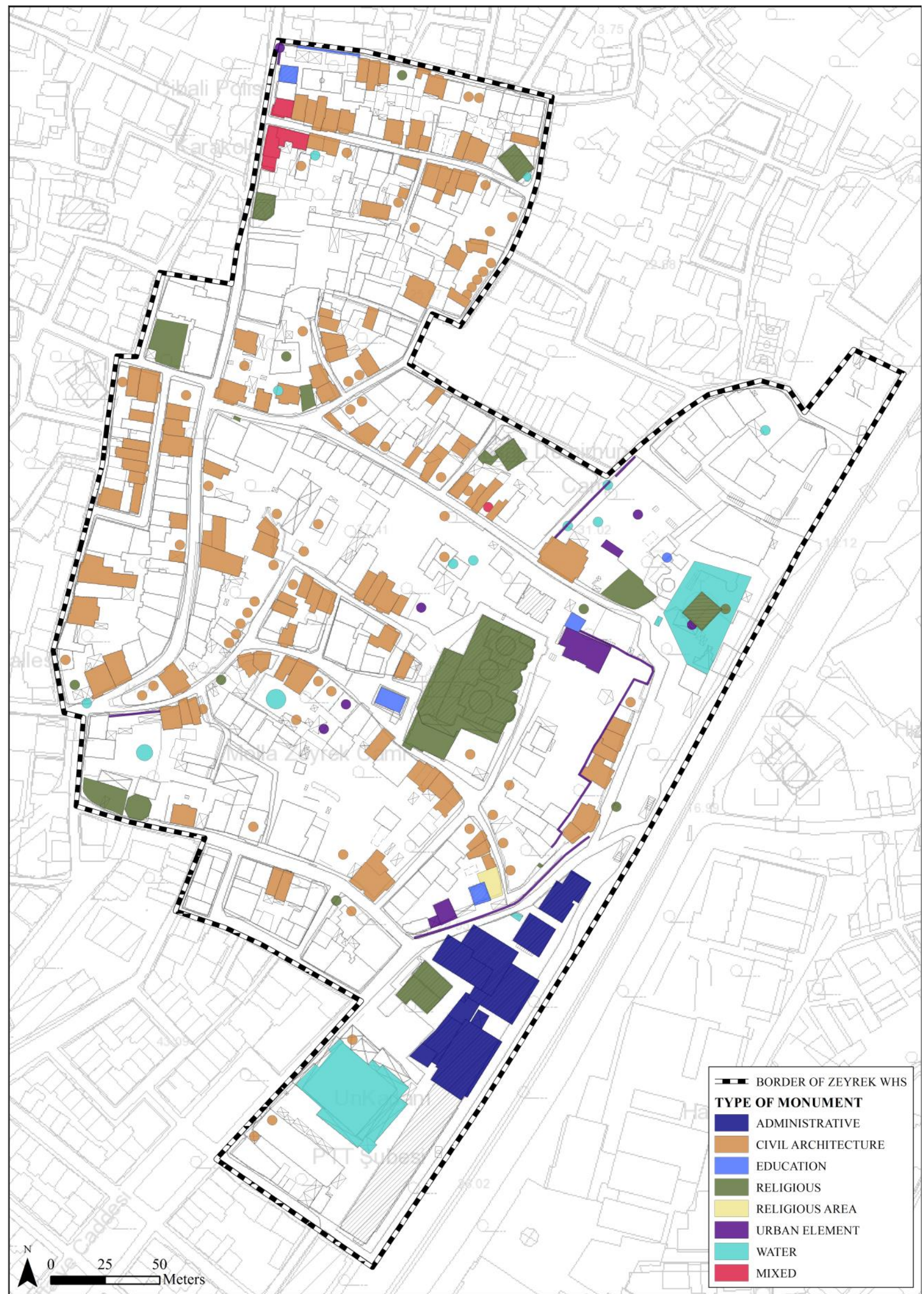

Figure 1. Type of Monument Analysis - Zeyrek WHS (2017) 


\subsection{Further Projects}

Database consist of 74 inquirable distinct data types which comes in integer, double, float, text, and date forms. This database can be used in further studies

- Thematic map creation; several different maps can be generated for Historical Peninsula in terms of monument types such as mosques (i.e. mosques of Ottoman Sultans), significant assets from Byzantine era, and art-works of Architect Sinan.

- Designating specific routes; for instance, a route intended to visit churches from 19th century can be produced via network analysis by using this database

- Generating new inventory based on a particular purpose; such as cemeteries or cisterns etc.

- Identifying the ruins for risk assessment and disaster management; for example specifying the timber-frame assets in order to take precautions to prevent the fires

- Reuse proposals for non-functional ones; for instance maintenance and repair of a madrasah and converting it into a cultural or educational facility

- Incentive and encouragement funds provided by public institutions for private-properties for maintenance and repairs

- Providing integration between GIS and BIM platforms for noteworthy assets in order to increase the efficiency

- Directing the proposed assets to the Preservation Boards

These sorts of studies can vary along with purpose and the content of the database.

\section{CONCLUSION}

Being a capital and homeland for different civilizations ensured Istanbul to have an outstanding cultural and architectural heritage. Even though various previous projects were initiated in different periods they could not achieve the main purpose due to being incomplete, inaccessible and inadequate.

It is aimed to document cultural assets in all over Istanbul and create identity cards for each one with the launch of Inventory of Istanbul Cultural Assets in 2015 by Istanbul Metropolitan Municipality. Feature data acquired through field work was linked with its corresponding spatial data. Several different validation and correction steps were taken in order to provide sufficient and improved data. Once the project is finished there will be an accessible, inquirable, accurate, sustainable information system and it will be shared with public and government institutions, decision-makers, universities, researchers, students and citizens. The project started in 2015 and it will be concluded in 2019 with the intent of update and revisions every once in 5 years.

Istanbul Cultural Assets database can be used in further researches and projects on account of including 74 distinct inquirable data types which will provide a base for such studies.

\section{REFERENCES}

Istanbul, 2011. Istanbul Tarihi Yarımada Yönetim Planı (The Management Plan for the Historical Peninsula of İstanbul).

Istanbul, 2018. Ístanbul Tarihi Yarımada Yönetim Planı (The Management Plan for the Historical Peninsula of İstanbul).

[website] (Istanbul Site Management Directorate) http://www.alanbaskanligi.gov.tr/istanbulun_tarihi_alanlari.htm 